\title{
Magnesium in Obesity, Metabolic Syndrome, and Type 2 Diabetes
}

\author{
Gabriele Piuri ${ }^{1,+}{ }^{\dagger}$, Monica Zocchi ${ }^{1,+} \oplus$, Matteo Della Porta ${ }^{1}(0)$, Valentina Ficara ${ }^{1}$, Michele Manoni ${ }^{2}(\mathbb{D}$, \\ Gian Vincenzo Zuccotti ${ }^{1,3}{ }^{\mathbb{D}}$, Luciano Pinotti ${ }^{2} \mathbb{D}$, Jeanette A. Maier ${ }^{1}$ and Roberta Cazzola ${ }^{1, *} \mathbb{C}$
}

1 Department of Biomedical and Clinical Sciences "L. Sacco", Università di Milano, 20157 Milan, Italy; gabriele.piuri@unimi.it (G.P.); monica.zocchi@unimi.it (M.Z.); matteo.dellaporta@unimi.it (M.D.P.); valentina.ficara@unimi.t (V.F.); gianvincenzo.zuccotti@unimi.it (G.V.Z.); jeanette.maier@unimi.it (J.A.M.)

2 Department of Health, Animal Science and Food Safety, Università di Milano, 20133 Milan, Italy; michele.manoni@unimi.it (M.M.); luciano.pinotti@unimi.it (L.P.)

3 Department of Pediatrics, Ospedale dei Bambini, 2154 Milan, Italy

* Correspondence: roberta.cazzola@unimi.it

+ These authors contributed equally to this work.

Citation: Piuri, G.; Zocchi, M.; Della Porta, M.; Ficara, V.; Manoni, M.; Zuccotti, G.V.; Pinotti, L.; Maier, J.A.; Cazzola, R. Magnesium in Obesity, Metabolic Syndrome, and Type 2 Diabetes. Nutrients 2021, 13, 320. https://doi.org/10.3390/nu13020320

Academic Editor: Mario Barbagallo Received: 30 November 2020

Accepted: 19 January 2021

Published: 22 January 2021

Publisher's Note: MDPI stays neutral with regard to jurisdictional claims in published maps and institutional affiliations.

Copyright: (c) 2021 by the authors. Licensee MDPI, Basel, Switzerland. This article is an open access article distributed under the terms and conditions of the Creative Commons Attribution (CC BY) license (https:// creativecommons.org/licenses/by/ $4.0 /)$.

\begin{abstract}
Magnesium $\left(\mathrm{Mg}^{2+}\right)$ deficiency is probably the most underestimated electrolyte imbalance in Western countries. It is frequent in obese patients, subjects with type- 2 diabetes and metabolic syndrome, both in adulthood and in childhood. This narrative review aims to offer insights into the pathophysiological mechanisms linking $\mathrm{Mg}^{2+}$ deficiency with obesity and the risk of developing metabolic syndrome and type 2 diabetes. Literature highlights critical issues about the treatment of $\mathrm{Mg}^{2+}$ deficiency, such as the lack of a clear definition of $\mathrm{Mg}^{2+}$ nutritional status, the use of different $\mathrm{Mg}^{2+}$ salts and dosage and the different duration of the $\mathrm{Mg}^{2+}$ supplementation. Despite the lack of agreement, an appropriate dietary pattern, including the right intake of $\mathrm{Mg}^{2+}$, improves metabolic syndrome by reducing blood pressure, hyperglycemia, and hypertriglyceridemia. This occurs through the modulation of gene expression and proteomic profile as well as through a positive influence on the composition of the intestinal microbiota and the metabolism of vitamins B1 and D.
\end{abstract}

Keywords: magnesium; magnesium deficiency; magnesium supplementation; obesity; metabolic syndrome; type 2 diabetes; gut microbiota; vitamin D

\section{Introduction}

Magnesium $\left(\mathrm{Mg}^{2+}\right)$ is the second most abundant intracellular cation and the fourth most abundant cation of the human body. Almost all the body $\mathrm{Mg}^{2+}$ is found in the bones (about $60 \%$ ) and soft tissues (about $40 \%$ ), while $<1 \%$ is in the blood. It is a cofactor of hundreds of enzymatic reactions, acting both on the enzymes as a structural or catalytic component and on the substrates. An example of $\mathrm{Mg}^{2+}$ bioactive activity is given by the reactions involving the complex Mg-ATP, which is an essential cofactor of kinases. For this reason, $\mathrm{Mg}^{2+}$ is a rate-limiting factor for many enzymes involved in carbohydrate and energy metabolism. Furthermore, $\mathrm{Mg}^{2+}$ is essential in the intermediary metabolism for the synthesis of the macromolecules [1]. Other vital $\mathrm{Mg}^{2+}$-dependent functions are muscle contraction and relaxation, normal neurological function, and release of neurotransmitters [2].

At the cellular level, $\mathrm{Mg}^{2+}$ homeostasis is fine-tuned by the coordinated activity of membrane channels and transporters. Some of them are ubiquitously expressed, such as transient receptor potential melastatin (TRPM) $7, \mathrm{Mg}^{2+}$ transporter 1 (MagT1) and solute carrier family 41 member 1 (SLC41A1). Others are tissue-specific, such as TRPM6, expressed in the kidney and the colon, cyclin and CBS domain divalent metal cation transport mediator cyclin M2 (CNNM2), expressed in the kidney, and CNNM4, expressed in the colon [3].

Obesity, metabolic syndrome, and type 2 diabetes mellitus are three interrelated conditions that share a series of pathophysiological mechanisms attributable to "low-grade" 
systemic inflammation [4]. $\mathrm{Mg}^{2+}$ deficit is frequent in obese subjects [3] and is a highly prevalent condition in patients with diabetes or metabolic syndrome. Moreover, it increases the risk of developing type- 2 diabetes [5]. Besides, $\mathrm{Mg}^{2+}$ depletion can promote chronic inflammation both directly [6-8] and indirectly by modifying the intestinal microbiota [9].

This review aims to offer insights into the pathophysiological mechanisms linking $\mathrm{Mg}^{2+}$ deficiency with obesity and the risk of developing metabolic syndrome and type 2 diabetes (Figure 1).

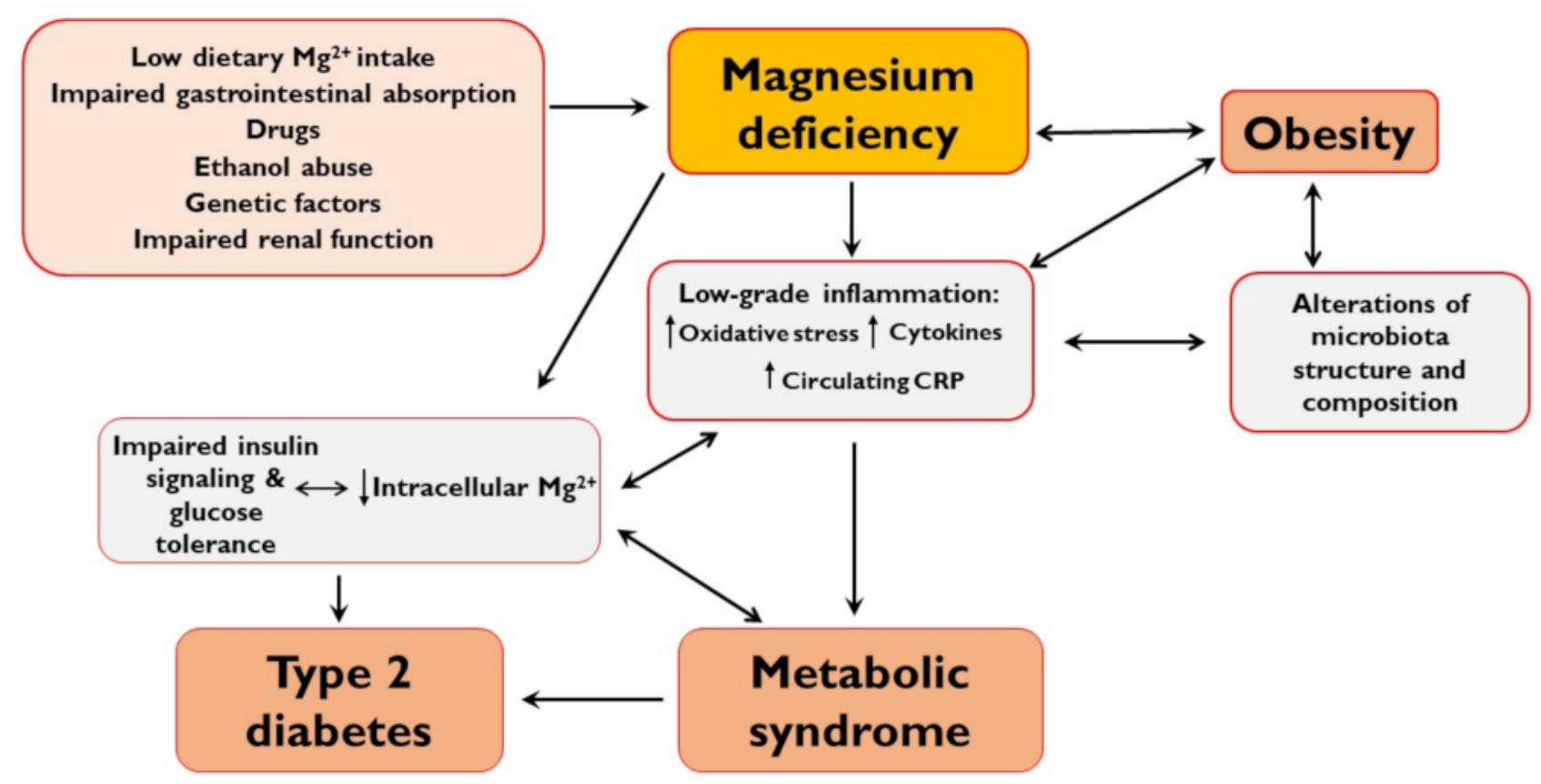

Figure 1. Physio-pathological mechanisms of magnesium deficiency in obesity, metabolic syndrome, and type 2 diabetes.

\section{2. $\mathrm{Mg}^{2+}$ Deficiency}

Among all the lab tests most frequently used to evaluate $\mathrm{Mg}^{2+}$ status in routine clinical practice is magnesemia because it is feasible and inexpensive $[1,10]$. However, magnesemia does not correlate with tissue pools because serum $\mathrm{Mg}^{2+}$ is just a tiny percentage of the intracellular/total body $\mathrm{Mg}^{2+}$ content [2]. This is one of the reasons why $\mathrm{Mg}^{2+}$ deficiency is the most underestimated electrolyte imbalance in Western countries, where a significantly high risk of latent hypomagnesemia occurs [11,12]. Based on distribution patterns of $\mathrm{Mg}^{2+}$ in the blood, the reference range for serum $\mathrm{Mg}^{2+}$ concentration is 0.75-0.95 mmol/L [13-16] and hypomagnesemia is generally defined as serum $\mathrm{Mg}^{2+}$ level lower than $0.7 \mathrm{mmol} / \mathrm{L}[3,17]$. Recently, a panel of experts proposed that urinary $\mathrm{Mg}^{2+}$ secretion should also be considered. Specifically, a magnesemia lower than $0.82 \mathrm{mmol} / \mathrm{L}$ with $\mathrm{Mg}^{2}$ urinary excretion of 40-80 mg/die should be considered indicative of $\mathrm{Mg}^{2} \mathrm{de}-$ ficiency [13]. Since serum $\mathrm{Mg}^{2+}$ content is only $1 \%$ of total $\mathrm{Mg}^{2+}$ in the body and is not representative for global intracellular $\mathrm{Mg}^{2+}$ status, $\mathrm{Mg}^{2+}$ deficiency may be underestimated and persist latently for years [16]. Subclinical hypomagnesemia is responsible for a variety of clinical manifestations that are non-specific and can overlap with symptoms of other electrolyte imbalances [18]. Some of these symptoms are depression, fatigue, muscle spasms and arrhythmias. Furthermore, a chronic low- $\mathrm{Mg}^{2+}$ status has been associated with an increased risk of chronic non-transmissible diseases, among which osteoporosis and sarcopenia [19-21]. Severe $\mathrm{Mg}^{2+}$ depletion, defined by serum $\mathrm{Mg}^{2+}$ concentration below 0.3-0.4 mmol/L, may lead to cardiac arrhythmias, tetany and seizures [3].

There are several causes of hypomagnesemia and one of the most relevant is an insufficient dietary intake. In fact, several studies show that the majority of the population in Europe and North America consumes less than the recommended daily allowance 
(RDA) of $\mathrm{Mg}^{2+}$, i.e., approximately $420 \mathrm{Mg}^{2+}$ for adult males and $320 \mathrm{Mg}^{2+}$ for adult females [22-24]. This deficit mainly derives from the Western-style diet (WD) that often contains only $30-50 \%$ of $\mathrm{Mg}^{2+}$ RDA. Indeed, the WD is based on massive consumption of processed foods, demineralized water and low amounts of vegetables and legumes, often grown in $\mathrm{Mg}^{2+}$-poor soil [18]. Hypomagnesemia may also be a consequence of pre-existing pathological conditions. For example, $\mathrm{Mg}^{2+}$ depletion is frequent in subjects affected by impaired gastrointestinal absorption caused by celiac disease [25], inflammatory bowel diseases [26-28] or in the presence of colon cancer, gastric bypass and other minor gastrointestinal disorders [29]. Additional causes of $\mathrm{Mg}^{2+}$ deficit are type 1 diabetes mellitus, renal disorders and hydro-electrolyte imbalances [30]. Hypomagnesemia is also associated, through different molecular mechanisms, with the frequent use of several medications such as diuretics (furosemide, thiazide), epidermal growth factor receptor inhibitors (cetuximab), calcineurin inhibitors (cyclosporine A), cisplatin and some antimicrobials (rapamycin, aminoglycosides antibiotics, pentamidine, foscaret, amphotericin B). It is also interesting to highlight that the wide use of proton pump inhibitors (PPI-omeprazole, pantoprazole, esomeprazole), which is generally considered safe, induces hypomagnesemia in $13 \%$ of the cases but the underlying mechanism is still unknown [31]. Moreover, ethanol abuse results in $\mathrm{Mg}^{2+}$ deficiency [32,33].

A low- $\mathrm{Mg}^{2+}$ status may also have genetic origins and derive from mutations of genes such as TRPM6, CLDN16-19 (claudin 16 and 19), KCNA1 (potassium voltage-gated channel subfamily A member 1), CNNM2 [34]. These mutations result in a severe hypomagnesemia accompanied by calcium wasting, renal failure, seizures and mental retardation [3]. Finally, from a physiological point of view, $\mathrm{Mg}^{2+}$ deficit may be observed after intensive sport activities with an increase in sweating, in healthy postmenopausal women [35] or during lactation [30]. Moreover, $\mathrm{Mg}^{2+}$ status is generally impaired in older people [36].

Considering the focus of this work, it is important to underline that a moderate or subclinical $\mathrm{Mg}^{2+}$ deficiency induces a chronic low-grade inflammation sustained by the release of inflammatory cytokines and production of free radicals, which exacerbate a preexisting inflammatory status [7]. For this reason $\mathrm{Mg}^{2+}$ depletion is considered a risk factor for pathological conditions characterized by chronic inflammation, such as hypertension and cardiovascular disorders but also metabolic syndrome and diabetes $[29,37,38]$.

\section{3. $\mathrm{Mg}^{2+}$ and Obesity}

Obesity and its comorbidities, including metabolic syndrome and type 2 diabetes, are a relevant medical problem worldwide. Obesity is the result of unhealthy diets, high in calories, but poor in essential nutrients. As a consequence, obese subjects are often $\mathrm{Mg}^{2+}$ deficient [39]. Indeed, the National Health and Nutrition Examination Survey (NHANES) 3 study underlines that $\mathrm{Mg}^{2+}$ deficit is more prevalent in subjects with body mass index (BMI) in the obese range than in the normal American population [40,41]. Analogously, $\mathrm{Mg}^{2+}$ intake is impaired in $35 \%$ of French individuals with BMI $>35 \mathrm{~kg} / \mathrm{m}^{2}$ [42]. The 30-year longitudinal CARDIA study, performed on more than 5000 subjects, indicates that $\mathrm{Mg}^{2+}$ intake is inversely associated with the incidence of obesity and with the levels of $\mathrm{C}$ reactive protein [43]. Besides, in animal models of diet-induced obesity $\mathrm{Mg}^{2+}$ supplementation prevents the accumulation of adipose tissue [44] and human studies report an inverse association between $\mathrm{Mg}^{2+}$ intake and markers of adiposity, such as BMI and waist circumference [45-47].

In obese subjects, most of the energy of the diet derives from refined grains and simple sugars and, consequently, their hepatic glucose catabolism is very active. Several key enzymes of glucose oxidation pathways are $\mathrm{Mg}^{2+-}$ dependent and $\mathrm{Mg}^{2+}$ is necessary also for the activation of vitamin B1 into thiamine diphosphate (TDP) that is another critical coenzyme of oxidative metabolism. Importantly, TDP-dependent enzymes require $\mathrm{Mg}^{2+}$ to reach optimal activation [48]. Therefore, low intracellular concentrations of $\mathrm{Mg}^{2+}$ and/or TDP may alter the oxidative metabolism of glucose. In the liver, a decrease of the activity of the $\mathrm{Mg}^{2+}$ - and TDP-dependent enzyme pyruvate dehydrogenase may 
divert glucose metabolism into the oxidative phase of the pentose phosphate pathway, thus generating an excess of NADPH [48]. NADPH provides essential redox potential for synthetic pathways, including fatty acid biosynthesis, thus promoting an increased synthesis of triglycerides and very low-density lipoprotein and, consequently, a higher triglyceride storage in adipocytes that increases the extent of obesity and the risk of obesity co-morbidities such as dyslipidemia, metabolic syndrome and type 2 diabetes [49-51].

Moreover, obese subjects are often deficient also in vitamin D [49,52] both in the presence and in the absence of type 2 diabetes [53], and $\mathrm{Mg}^{2+}$ is essential also for vitamin D synthesis and activation [54]. A randomized controlled trial suggests that optimal $\mathrm{Mg}^{2+}$ status may be fundamental for optimizing vitamin D status [55]. Because of its role in the renin-angiotensin system and its immunomodulatory properties, vitamin $\mathrm{D}$ deficiency is identified as a potential risk factor in cardiometabolic disorders, including insulin resistance, metabolic syndrome and cardiovascular diseases [56]. Moreover, chronic latent $\mathrm{Mg}^{2+}$ deficiency and/or Vitamin D deficiency predispose non-diabetic obese subjects to an increased risk of cardiometabolic diseases. Meanwhile, maintaining a normal $\mathrm{Mg}^{2+}$ status improves the beneficial effect of Vitamin D on cardiometabolic risk indicators [57]. Interestingly, an interventional study performed on healthy women showed a significant increase in serum concentration of $\mathrm{Mg}^{2+}$ in obese but not in non-obese subjects after vitamin $\mathrm{D}$ intramuscular injection, probably caused by increased $\mathrm{Mg}^{2+}$ renal retention induced by vitamin $\mathrm{D}$ and emphasized by baseline $\mathrm{Mg}^{2+}$ deficiency of the obese subjects [58].

\section{4. $\mathrm{Mg}^{2+}$ in Metabolic Syndrome}

Obesity and metabolic syndrome (MetS) are both characterized by excessive accumulation of body fat. However, while obesity only implies the accumulation of excess body fat, metabolic syndrome is a disorder of accumulation and use of energy, promoted by low-grade systemic inflammation, and resulting in central adiposity, hypertension, dyslipidemia, or insulin resistance. Many studies have found a positive correlation between low dietary $\mathrm{Mg}^{2+}$ intake and MetS risk independently from other risk factors such as age, gender, BMI, race, educational attainment, marital status, smoking, alcohol intake, exercise, energy intake, percentage of calories from saturated fat, use of an antihypertensive or lipid medication [59-64]. Dibaba et al. showed in the last meta-analysis available that the dietary $\mathrm{Mg}^{2+}$ intake is inversely associated with the prevalence of MetS [63]. A recent crosssectional analysis performed in a large Chinese population reports an inverse correlation between dietary $\mathrm{Mg}^{2+}$ intake and the prevalence of MetS [65]. In more than 11.000 middleaged and older women high dietary $\mathrm{Mg}^{2+}$ intake lowers systemic inflammation and the risk of the MetS [59]. An interesting Serbian study shows a positive association between chronic exposure to insufficient $\mathrm{Mg}^{2+}$ in drinking municipalities water and the prevalence of hypertension and MetS [66].

MetS exponentially increases the risk of developing type 2 diabetes, cardiovascular disease and, in general, morbidity and mortality. Proper $\mathrm{Mg}^{2+}$ intake reduces cardiometabolic risk and is associated with a reduced hazard of cardiovascular disease, diabetes, and allcause mortality [67-70]. Likewise, higher levels of circulating $\mathrm{Mg}^{2+}$ are associated with a lower risk of cardiovascular disease, mainly coronary artery disease [71].

Low chronic $\mathrm{Mg}^{2+}$ dietary intake leads to serum and intracellular $\mathrm{Mg}^{2+}$ deficiency. This is particularly evident in obese people with MetS, in elderly subjects and non-white people with insulin resistance [72-74].

$\mathrm{Mg}^{2+}$ is a natural calcium $\left(\mathrm{Ca}^{2+}\right)$ antagonist, and its metabolic effect needs to be discussed according to $\mathrm{Ca}^{2+}$ concentration. A recent meta-analysis suggests that high $\mathrm{Ca}^{2+}$ dietary intake reduces the risk of MetS [75]. Other experimental data suggest that a higher $\mathrm{Ca}^{2+} / \mathrm{Mg}^{2+}$ intracellular ratio, induced by a diet high in $\mathrm{Ca}^{2+}$ and low in $\mathrm{Mg}^{2+}$, may lead to hypertension, insulin resistance, and MetS [76]. Accordingly, subjects who meet the recommended daily allowance for both $\mathrm{Mg}^{2+}$ and $\mathrm{Ca}^{2+}$ have reduced risk of MetS [76]. $\mathrm{Mg}^{2+}$ and $\mathrm{Ca}^{2+}$ work together to regulate the metabolic response of overweight and obese 
subjects, and an unbalanced $\mathrm{Ca}^{2+} / \mathrm{Mg}^{2+}$ ratio maximizes the effect of their single deficiency. The optimal $\mathrm{Ca}^{2+} / \mathrm{Mg}^{2+}$ ratio leads to the best-decreased risk of MetS $[77,78]$.

\section{5. $\mathrm{Mg}^{2+}$ in Type 2 Diabetes}

Type 2 diabetes (T2D) is often associated with altered $\mathrm{Mg}^{2+}$ homeostasis and $\mathrm{Mg}^{2+}$ intake is inversely associated with the risk of T2D in a dose-response manner $[79,80]$. Epidemiologic studies have shown a high prevalence of hypomagnesemia in subjects with T2D $[81,82] . \mathrm{Mg}^{2+}$ depletion in patients with T2D is mainly caused by a low intake and an increased urinary loss of $\mathrm{Mg}^{2+}$, probably resulting from impaired renal function [82]. Moreover, recent findings demonstrate that hypomagnesemia is strongly associated with the progression of T2D [83]. In particular, if it is true that insulin regulates $\mathrm{Mg}^{2+}$ homeostasis, at the same time $\mathrm{Mg}^{2+}$ is also a significant determinant of post-receptor insulin signaling. The influence of $\mathrm{Mg}^{2+}$ on glucose metabolism, insulin sensitivity, and insulin action could explain the negative association between $\mathrm{Mg}^{2+}$ intake and T2D incidence [82,84-87] (Figure 2). To better understand this issue, it is worth recalling that insulin secretion is started by a Ca2+ influx that is competitively inhibited by extracellular $\mathrm{Mg}^{2+}$ and, consequently, insulinemia is inversely correlated with magnesemia. Circulating glucose is easily taken from cells $\beta$ through the glucose transporter 2 (GLUT2), and then converted in glucose-6-phosphate (G6P) by glucokinase (GK). The oxidation of G6P in glycolysis determines an increase in the ATP/ADP ratio leading to the closure of ATP-sensitive $\mathrm{K}^{+}$channels (KATP channels) and, consequently, to the depolarization of the membrane, followed by the opening of voltage-dependent $\mathrm{Ca}^{2+}$ channels [88]. The increase in intracellular concentrations of $\mathrm{Ca}^{2+}$ triggers the fusion of insulin-containing granules with the membrane and the subsequent release of their content. The molecular mechanisms by which $\mathrm{Mg}^{2+}$ contributes to insulin resistance are mostly unrevealed. However, it is accepted that $\mathrm{Mg}^{2+}$ deficiency has a significant impact on insulin secretion and may contribute to dysfunction of pancreatic beta cells in T2D [89]. This depends on the key roles played by $\mathrm{Mg}^{2+}$ in the glucose-dependent signaling inducing insulin release. The activities of GK and many glycolytic enzymes depend on Mg-ATP complex, thus, a low intracellular $\mathrm{Mg}^{2+}$ concentration results in decreased ATP level in the cells. In addition, the closure of KATP channels depends on ATP binding to the Kir6.2 subunit, while the opening of these channels depends on Mg-ATP binding to the SUR1 subunit. The reduction in the intracellular levels of both ATP and Mg-ATP deranges the fine regulation of KATP channels. This leads to an increase in the basal secretion of insulin and induces hyperinsulinemia, thus contributing to a chronic exposure of cells to insulin and to the development of insulin resistance fostered also by the concomitant low grade inflammation [89]. Moreover, the prolonged hyperinsulinemia typical of insulin resistance induces an increase in renal excretion of $\mathrm{Mg}^{2+}$, thus perpetuating a vicious cycle [90]. In addition, we recall that physiological concentrations of insulin and glucose stimulate $\mathrm{Mg}^{2+}$ transport, thus increasing intracellular $\mathrm{Mg}^{2+}$ content. It is noteworthy that low intracellular $\mathrm{Mg}^{2+}$ impairs cell responsiveness to insulin, because low intracellular $\mathrm{Mg}^{2+}$ alters the tyrosine-kinase activity of the insulin receptor (INSR), leading to the development of post-receptor insulin resistance and decreased cellular glucose utilization [89,91]. In particular, $\mathrm{Mg}^{2+}$ and $\mathrm{Mg}$-ATP complex are key regulators of the PI3K/Akt kinase pathway downstream to the INSR. This pathway starts with INSR auto-phosphorylation, which triggers the downstream kinase cascade. Insulin receptor substrate (IRS) mainly activates phosphatidylinositol-4,5-bisphosphate-3-kinase (PI3K), which generates the second messenger phosphatidylinositol-3,4,5-triphosphate (PIP3). PIP3 activates 3-phosphoinositide dependent protein kinase-1 (PDK1), which activates Akt. Akt regulates the metabolic actions of insulin, including glucose uptake by GLUT4 mobilization in skeletal muscle and adipose tissue, glycogen and protein synthesis and lipogenesis. For this reason, the lower is the basal intracellular $\mathrm{Mg}^{2+}$ concentration, the higher is the amount of insulin required to metabolize the same glucose load, indicating decreased insulin sensitivity $[89,91]$. All these data underline that insulin action is strictly dependent on the intracellular $\mathrm{Mg}^{2+}$ concentration. 


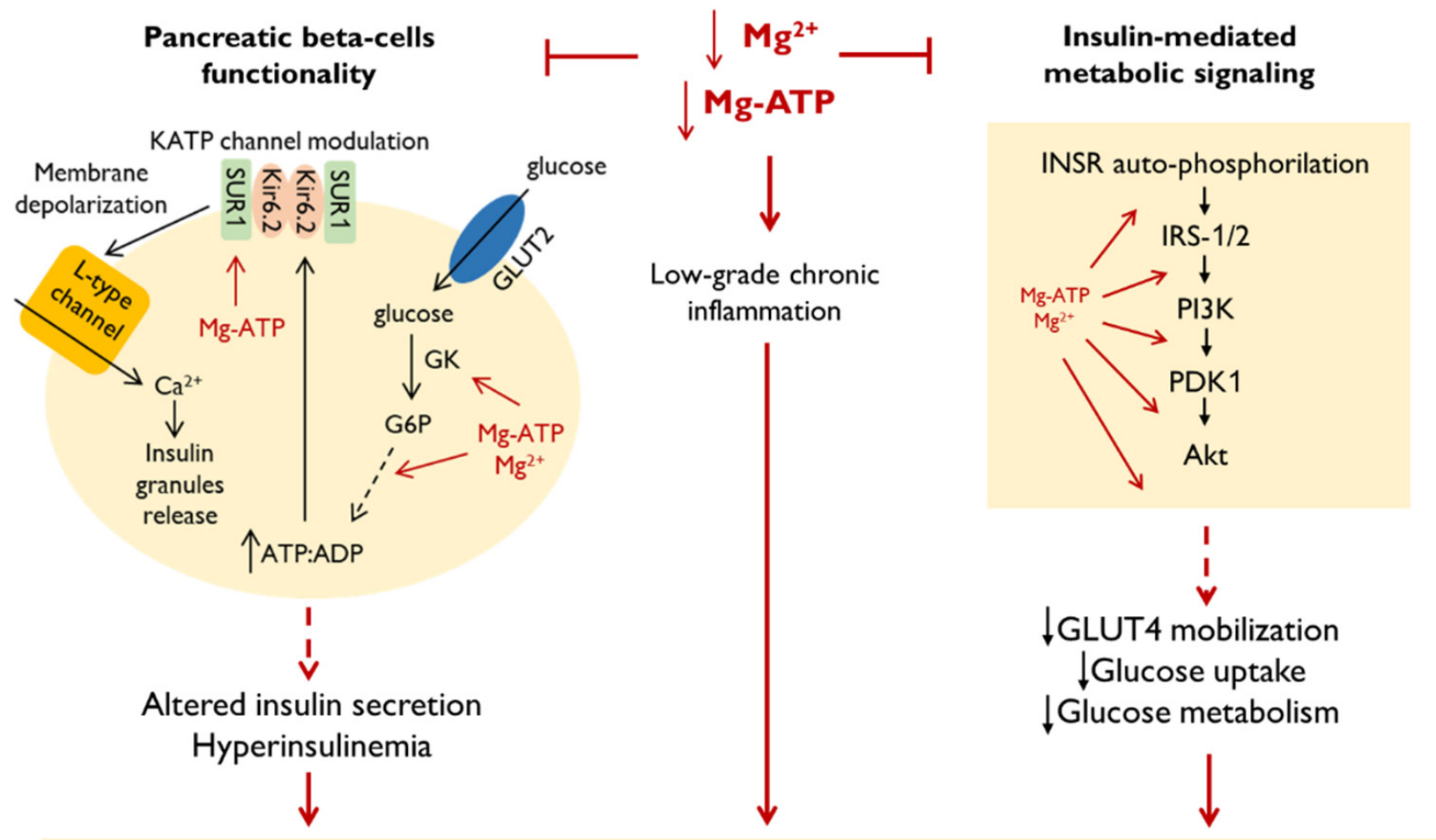

\section{INSULIN RESISTANCE}

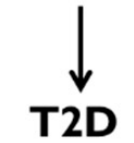

Figure 2. Links between $\mathrm{Mg}^{2+}$ and insulin signaling. For details, please see the text.

$\mathrm{Mg}^{2+}$ deficiency can also contribute to T2D through the modulation of $\mathrm{Na}^{+} / \mathrm{K}^{+}-$ ATPase that is crucial for maintaining the membrane potential and low cytoplasmic sodium concentration. $\mathrm{Mg}^{2+}$ ions drive the conformational change of the sodium pump whose dysfunction has been correlated to T2D [92,93]. Moreover, some single nucleotide polymorphisms in the TRPM6 gene are associated with an increased risk of developing T2D because TRPM6 cannot be activated by insulin in the presence of these mutations [94].

The observation that several pharmacological treatments for diabetes, such as metformin, appear to increase $\mathrm{Mg}^{2+}$ levels further supports this assumption and suggests a substantial interdependence between $\mathrm{Mg}^{2+}$ deficiency and the development of insulin resistance and T2D. $\mathrm{Mg}^{2+}$ deficiency may not be a secondary consequence of T2D, but it may contribute to insulin resistance and altered glucose tolerance, thereby leading to T2D [82].

Few studies have discussed the relationship between hypomagnesemia and metabolic disorders in childhood and adolescence. $\mathrm{Mg}^{2+}$ deficiency in obese children may be secondary to decreased dietary $\mathrm{Mg}^{2+}$ intake. Obese children show lower serum $\mathrm{Mg}^{2+}$ levels than the normal-weight control group. In obese children and adolescents, $\mathrm{Mg}^{2+}$ blood concentration is inversely correlated with the degree of obesity and is related to an unfavorable serum lipid profile and higher systemic blood pressure than healthy controls [95,96]. The association between $\mathrm{Mg}^{2+}$ deficiency and insulin resistance has been described also in childhood [97]. $\mathrm{Mg}^{2+}$ supplementation or increased intake of $\mathrm{Mg}^{2+}$-rich foods to correct its deficiency may represent an essential and inexpensive tool in preventing T2D in obese children. 


\section{6. $\mathrm{Mg}^{2+}$ and Gut Microbiota}

The gut microbiota is a complex microbial ecosystem, symbiotic with humans, that plays a crucial role in a series of pathophysiological processes. In healthy subjects the gut microbiota is rich in microbial species and, through its genes and metabolites (i.e., shortchain fatty acids, amino acid derivatives, secondary bile acid), it acts as an immunologic and metabolic organ $[98,99]$. By contrast, obesity and related metabolic disorders, such as MetS and T2D, determine profound functional and compositional alterations in the intestinal microbiota, collectively referred to as dysbiosis [100].

Little is known about $\mathrm{Mg}^{2+}$ deficiency and gut microbiota in humans, while some data are available in animal models. A 6-week $\mathrm{Mg}^{2+}$-deficient diet in rodents altered the gut microbiota and was associated with anxiety-like behavior [101]. In particular, $\mathrm{Mg}^{2+}$ deficiency may mediate an imbalance of the microbiota-gut-brain axis, which contributes to the development of depressive-like behavior [102]. It should be pointed out that obesity increases the risk of depression and depression was found to be predictive of developing obesity [103]. Moreover, epidemiological data have demonstrated that obesity is an important risk factor for the development of gastroesophageal reflux disease [104] and PPI used for the treatment of such disease, may lead to $\mathrm{Mg}^{2+}$ deficiency also through the involvement of the gut microbiome [105]. As previously mentioned, $\mathrm{Mg}^{2+}$ deficiency is a nutritional disorder connected to a low-grade, latent chronic inflammatory state. Interestingly, in $\mathrm{Mg}^{2+}$-deficient mice, changes in intestinal bifidobacteria levels are associated with an inflammatory response, thus creating an effective link between $\mathrm{Mg}^{2+}$ status, gut microbiota and inflammation [106].

It is now widely accepted that an altered gut microbiota composition participates in systemic low-grade inflammation [107-110]. An analysis of patients with different glucose tolerance suggests that both structure and diversity of gut microbiota are altered in the presence of impaired glucose regulation and T2D [111,112]. However, Thingholm et al. compared the microbiota composition of obese versus lean subjects and obese versus obese with T2D. The authors observed that microbiome diversity and functionality were significantly reduced in obese compared to lean subjects, while only modest differences emerged when comparing the microbiome of obese versus obese with T2D [113]. Therefore, the development of obesity-associated T2D could be related to a progressive disruption of the gut microbiome. Gut microbiota manipulation through dietary adjustment has become an important research direction in T2D prevention and therapy. In this perspective, $\mathrm{Mg}^{2+}$ supplementation might help in remodeling the microbiota. Indeed, $\mathrm{Mg}^{2+}$ supplementation in obese subjects with and without T2D affects microbial composition and functional potential [113]. Moreover, dietary supplementation with a multi-mineral functional food derived from seaweed and seawater, rich in bioactive $\mathrm{Mg}^{2+}$ and other trace elements, significantly enhances the gut microbial diversity in adult male rats [114].

To conclude, an adequate $\mathrm{Mg}^{2+}$ dietary intake could positively affect the composition of the intestinal microbiota and, consequently, the host metabolism, thus helping in preventing metabolic alterations associated with the development of MetS and TD2. However, the path for clarifying the impact of $\mathrm{Mg}^{2+}$ in this emerging field of research is still long.

\section{Dietary $\mathrm{Mg}^{2+}$}

The intakes of food rich in $\mathrm{Mg}^{2+}$, including whole grains, nuts and seeds, legumes, and dark-green vegetables, were associated with a lower incidence of obesity, T2D and MetS [43]. Therefore, correcting unhealthy diets is a priority to meet the daily-recommended requirement for $\mathrm{Mg}^{2+}$. However, because of agronomic and environmental factors as well as food processing, $\mathrm{Mg}^{2+}$ content in fruits and vegetables dropped in the last 50 years [115] and it might be necessary to supplement it. This is an approach that has been proven beneficial in T2D and MetS (Figure 2). The daily administration of $250 \mathrm{mg}$ of elemental $\mathrm{Mg}^{2+}$ for three months improves glycemic control in T2D subjects as demonstrated by the significant reduction of glycated hemoglobin, insulin levels, C-peptide, and Homeostatic Model Assessment for Insulin Resistance (HOMA-IR) [116]. This effect is probably due 
to the correction of an underlying latent $\mathrm{Mg}^{2+}$ deficiency. Indeed, the supplementation with $360 \mathrm{mg}$ of $\mathrm{Mg}^{2+}$ for the same period does not improve insulin sensitivity in normomagnesemic T2D patients [117]. The administration of $250 \mathrm{mg}$ of elemental $\mathrm{Mg}^{2+}$ for 12 weeks improved the wound healing of diabetic foot ulcers, decreasing the lesion size, and ameliorating glucose metabolism [118]. Mg2+ could also affect glucose metabolism by modulating the concentration of inflammatory cytokines, such as IL-6. Although these data need to be confirmed, in prediabetic subjects, the supplementation with $380 \mathrm{mg}$ of $\mathrm{Mg} 2+$ provides a trend of reduction in IL-6 plasmatic levels while there are no differences in the levels of C-reactive protein (CRP), Tumor Necrosis Factor-alpha (TNF-alpha), and Interleukin 10 (IL-10) [119]. It is noteworthy that, in apparently healthy runners fed a low Mg2+ diet, the administration of $500 \mathrm{mg}$ of Mg2+ lowers IL-6 levels, reduces muscle soreness and increases post-exercise blood glucose [120].

$\mathrm{Mg}^{2+}$ supplementation seems to improve blood pressure control and vascular resistance in patients with essential hypertension [121]. The administration of $300 \mathrm{mg}$ of $\mathrm{Mg}^{2+}$ for one month decreases systolic and diastolic pressures, systemic vascular resistance, and left cardiac work [122]. The oral $\mathrm{Mg}^{2+}$ supplementation with $600 \mathrm{mg}$ for 12 weeks is associated with moderate but consistent ambulatory blood pressure reduction in patients with mild hypertension [123]. This result can be explained by the evidence that $\mathrm{Mg}^{2+}$ is a $\mathrm{Ca}^{2+}$ antagonist, increases the synthesis of vasodilators such as prostacyclin and nitric oxide, and inhibits vascular calcifications through the modulation of TRPM7 [123,124]. An increase in the transcription of the $\mathrm{Mg}^{2+}$ channel TRPM6 could explain the antihypertensive effects of $\mathrm{Mg}^{2+}$ supplementation. The increase of TRPM6 mRNA expression is obtained with the administration of $360 \mathrm{mg}$ of $\mathrm{Mg}^{2+}$ for four months [124]. The positive effect of $\mathrm{Mg}^{2+}$ supplementation on blood pressure is also reported in patients already undergoing drug treatment for hypertension. In thiazide-treated women, the administration of $600 \mathrm{mg}$ of $\mathrm{Mg}^{2+}$ improves endothelial function and subclinical atherosclerosis [125]. In hemodialysis patients, the administration of $440 \mathrm{mg}$ of $\mathrm{Mg}^{2+}$ for six months decreases carotid intimatemedia thickness, which is a marker of cardiovascular disease. This effect is not associated with an improvement of endothelial function measured by brachial artery flow-mediated dilatation and might be explained by the modulation of calcification through the regulation of calcium and phosphorus concentration in blood [126]. In disagreement with the aforementioned results, a randomized controlled trial on overweight and obese middle-aged and elderly adults did not report any improvement of endothelial function and cardiometabolic risk markers after supplementing $350 \mathrm{mg} \mathrm{Mg}^{2+}$ daily for 24 weeks [126,127].

Since correcting $\mathrm{Mg}^{2+}$ status lowers blood pressure, corrects lipid profile and ameliorates the control of glycemia, it is not surprising that $\mathrm{Mg}^{2+}$ supplementation has positive effects in MetS. The supplementation of $380 \mathrm{mg}$ of $\mathrm{Mg}^{2+}$ for 16 weeks improves MetS by reducing blood pressure, hyperglycemia, and hypertriglyceridemia [128], because the correction of hypomagnesemia leads to changes in gene expression and proteomic profiling consistent with favorable effects on several metabolic pathways [85]. The effect of $\mathrm{Mg}^{2+}$ on the lipid profile is still debated and appears to be mediated by the improvement of insulin resistance and appears to be present only if $\mathrm{Mg}^{2+}$ supplementation corrects a previous deficiency [129]. The administration of $370 \mathrm{mg}$ of $\mathrm{Mg}^{2+}$ in healthy normomagnesemic young men with a family history of MetS does not show beneficial effects on blood pressure, vascular function, and glycolipid profile [130]. For MetS, as well as for T2D, the positive effect of $\mathrm{Mg}^{2+}$ administration is only registered if the supplementation corrects a condition of hypomagnesemia.

Some critical issues emerge from the analysis of the literature and complicate the interpretation of the data (Table 1). First, there is no agreement on the dosages and timing of $\mathrm{Mg}^{2+}$ supplementation in the treatment of MetS, T2D, and hypertension. Considering the literature just discussed [109-124], the dosage of $\mathrm{Mg}^{2+}$ varies from $250 \mathrm{mg}$ to $600 \mathrm{mg}$, with a median of $380 \mathrm{mg}$ (95\% confidence interval (CI) 300-500 mg). The time of $\mathrm{Mg}^{2+}$ supplementation ranges between 7 days and six months, with a median of about three months (95\% CI 4-24 weeks). Besides, there is no consensus on the type of $\mathrm{Mg}^{2+}$ salt to 
use. The bioavailability of different $\mathrm{Mg}^{2+}$ salts has been investigated in depth [131-134]. Magnesium sulfate, oxide, carbonate, chloride, citrate, malate, acetate, gluconate, lactate, aspartate, fumarate, acetyl taurate, bis-glycinate, and pidolate are all employed in $\mathrm{Mg}^{2+}$ supplementation. In part, the differences in the bioavailability of $\mathrm{Mg}^{2+}$ salt is due to their different solubility [135]. Although organic $\mathrm{Mg}^{2+}$ salts were slightly more bioavailable than inorganic $\mathrm{Mg}^{2+}$ salts, inorganic $\mathrm{Mg}^{2+}$ salts have been administered to patients with interesting clinical outcomes. The choice of the type of $\mathrm{Mg}^{2+}$ salt based on its bioavailability conditions its dosage and the possible side effects, especially as intestinal symptoms of osmotic dysentery [136] (Figure 3).

Table 1. A quick recap of the last and most relevant clinical trials describing the effects of $\mathrm{Mg}^{2+}$ supplementation on obesity, metabolic syndrome (MetS), and type 2 diabetes (T2D).

\begin{tabular}{|c|c|c|c|c|c|c|}
\hline Author(s) & Year & $\begin{array}{l}\text { Dosage of } \mathrm{Mg}^{2+} \\
\text { Supplementation }\end{array}$ & Type of Salt & $\begin{array}{l}\text { Timing of } \mathrm{Mg}^{2+} \\
\text { Supplementation }\end{array}$ & $\begin{array}{c}\text { Effects of } \mathrm{Mg}^{2+} \\
\text { Supplementation }\end{array}$ & Ref. \\
\hline $\begin{array}{l}\text { Elderawi WA } \\
\text { et al. }\end{array}$ & 2018 & $250 \mathrm{mg} /$ day & $\begin{array}{l}\text { Oxide, } \\
\text { gluconate, } \\
\text { lactate }\end{array}$ & 3 months & $\begin{array}{l}\text { Improves glycemic control in } \\
\text { T2D subjects with a reduction } \\
\text { of glycated hemoglobin, } \\
\text { insulin levels, C-peptide, and } \\
\text { HOMA-IR. }\end{array}$ & [116] \\
\hline $\begin{array}{l}\text { Navarrete-Cortes } \\
\text { A et al. }\end{array}$ & 2014 & $360 \mathrm{mg} /$ day & Lactate & 3 months & $\begin{array}{c}\text { No effects on insulin } \\
\text { sensitivity. }\end{array}$ & [117] \\
\hline Razzaghi R et al. & 2018 & $250 \mathrm{mg} /$ day & Oxide & 12 weeks & $\begin{array}{l}\text { Improves wound healing of } \\
\text { diabetic foot ulcers, decreasing } \\
\text { the lesion size, and } \\
\text { ameliorating glucose } \\
\text { metabolism. }\end{array}$ & [118] \\
\hline $\begin{array}{l}\text { Simental-Mendía } \\
\text { LE et al. }\end{array}$ & 2012 & $380 \mathrm{mg} /$ day & Chloride & 3 months & Reduces IL-6 plasmatic levels. & [119] \\
\hline Steward CJ et al. & 2019 & $500 \mathrm{mg} /$ day & $\begin{array}{l}\text { Oxide, } \\
\text { stearate }\end{array}$ & 7 days & $\begin{array}{l}\text { Lowers IL-6 levels, reduces } \\
\text { muscle soreness and increases } \\
\text { post-exercise blood glucose. } \\
\text { Decreases systolic and }\end{array}$ & [120] \\
\hline Banjanin $\mathrm{N}$ et al. & 2018 & $300 \mathrm{mg} /$ day & Oxide & 1 month & $\begin{array}{c}\text { diastolic pressures, systemic } \\
\text { vascular resistance, and left } \\
\text { cardiac work. }\end{array}$ & [122] \\
\hline $\begin{array}{l}\text { Hatzistavri LS } \\
\quad \text { et al. }\end{array}$ & 2009 & $600 \mathrm{mg} /$ day & Pidolate & 12 weeks & $\begin{array}{c}\text { Reduces ambulatory blood } \\
\text { pressure. }\end{array}$ & [123] \\
\hline $\begin{array}{l}\text { Rodríguez- } \\
\text { Ramírez M } \\
\quad \text { et al. }\end{array}$ & 2017 & $360 \mathrm{mg} /$ day & Lactate & 4 months & $\begin{array}{l}\text { Increases TRPM6 mRNA } \\
\text { relative expression. }\end{array}$ & [124] \\
\hline Cunha AR et al. & 2017 & $600 \mathrm{mg}$ twice a day & $\begin{array}{l}\text { Chelate (not } \\
\text { better } \\
\text { specified) }\end{array}$ & 6 months & $\begin{array}{l}\text { Improves endothelial function } \\
\text { and subclinical atherosclerosis. }\end{array}$ & [125] \\
\hline $\begin{array}{l}\text { Mortazavi M } \\
\quad \text { et al. }\end{array}$ & 2013 & $\begin{array}{c}440 \text { mg } 3 \text { times per } \\
\text { week }\end{array}$ & Oxide & 6 months & $\begin{array}{c}\text { Decreases carotid } \\
\text { intimate-media thickness, } \\
\text { which is a marker of } \\
\text { cardiovascular disease. }\end{array}$ & [126] \\
\hline Joris PJ et al. & 2017 & $350 \mathrm{mg} /$ day & Citrate & 24 weeks & $\begin{array}{l}\text { No effect on endothelial } \\
\text { function. }\end{array}$ & [127] \\
\hline $\begin{array}{l}\text { Rodríguez- } \\
\text { Morán M } \\
\text { et al. }\end{array}$ & 2018 & $380 \mathrm{mg} /$ day & Chloride & 16 weeks & $\begin{array}{c}\text { Improves MetS by reducing } \\
\text { blood pressure, } \\
\text { hyperglycemia, and } \\
\text { hypertriglyceridemia. }\end{array}$ & [128] \\
\hline Cosaro E et al. & 2014 & $370 \mathrm{mg}$ twice a day & Pidolate & 8 weeks & $\begin{array}{l}\text { Effects on blood pressure, } \\
\text { vascular function, and } \\
\text { glycolipid profile. }\end{array}$ & [130] \\
\hline
\end{tabular}

HOMA-IR: Homeostasis Model Assessment-estimated for Insulin Resistance; IL-6: Interleukin-6; TRPM6: Transient Receptor Potential Melastatin 6. 

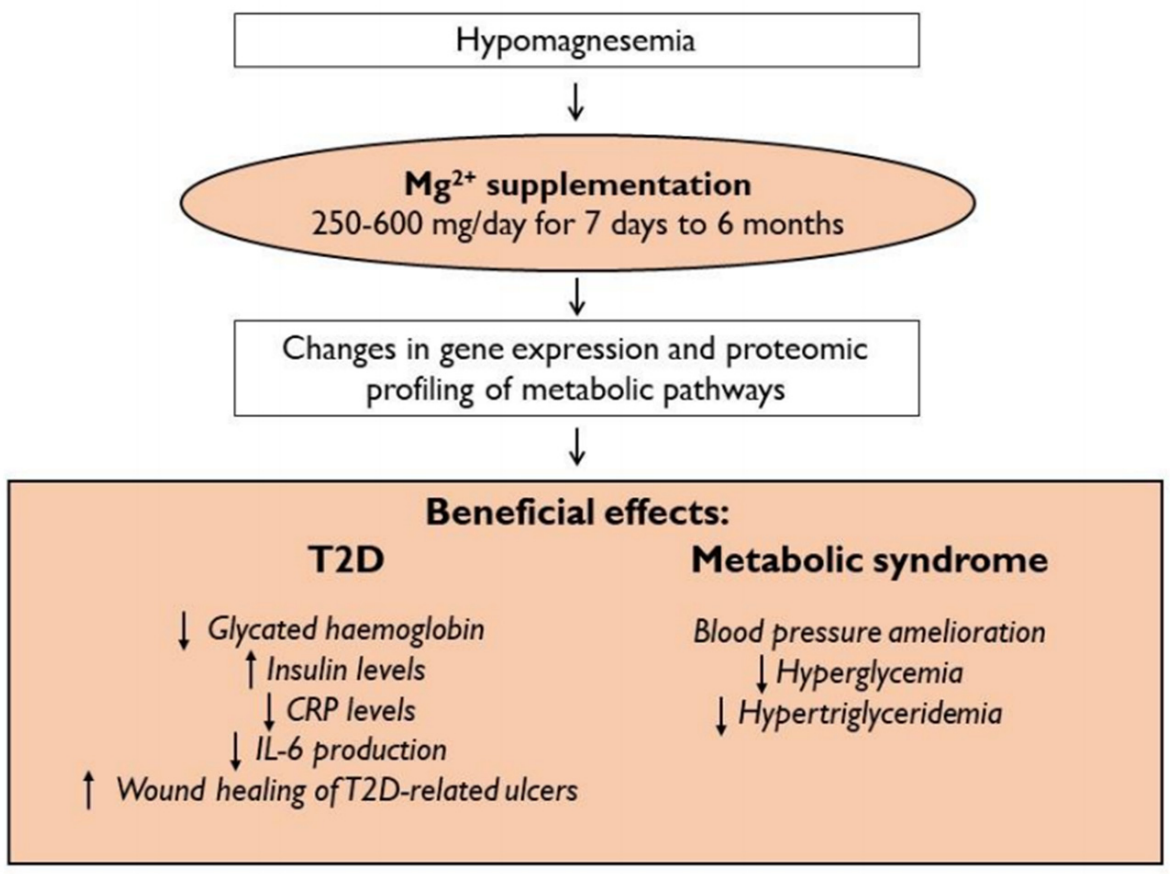

Figure 3. Beneficial effects of magnesium supplementation in hypomagnesemic patients with metabolic syndrome and type 2 diabetes.

\section{Conclusions}

Obesity, type 2 diabetes, and metabolic syndrome are intertwined conditions characterized by chronic low-grade inflammation partly attributable to $\mathrm{Mg}^{2+}$ deficiency. In metabolic diseases, a low $\mathrm{Mg}^{2+}$ status mainly due to unhealthy diets contributes to generate a pro-inflammatory environment that exacerbates metabolic derangement. $\mathrm{Mg}^{2+}$ supplementation seems to foment the correction of this vicious loop, but at the moment it is hard to interpret whether $\mathrm{Mg}^{2+}$ beneficial effects occur through a direct effect on metabolic pathways or an indirect action on inflammation, or both.

Several important points need to be clarified. At the clinical level, more studies are necessary to define which $\mathrm{Mg}^{2+}$ salt and which dosage guarantee better outcomes. In addition, the investigation of microbiota in hypomagnesemic subjects might provide interesting hints and suggest targeted dietary approaches aimed at harmonizing the gut microbial ecosystem. In addition, biomarkers that grant the possibility of evaluating $\mathrm{Mg}^{2+}$ homeostasis should be identified. At the cellular and molecular level, it is important to focus on the role of intracellular $\mathrm{Mg}^{2+}$ in modulating cell function, from the regulation of metabolism to the release of inflammatory mediators.

Considering the worldwide prevalence of obesity, type 2 diabetes and metabolic syndrome, the correction of bad dietary habits and, eventually, the supplementation of $\mathrm{Mg}^{2+}$ might represent an inexpensive but valuable tool to contain the occurrence and the progression of these conditions.

Funding: This research received no external funding. The APC was funded by University of Milan.

Informed Consent Statement: Not applicable.

Data Availability Statement: Data sharing is not applicable to this article.

Acknowledgments: The authors acknowledge support from the University of Milan through the APC initiative. Moreover, this work was developed as part of the PhD program in Nutrition Sciences, University of Milan.

Conflicts of Interest: The authors declare no conflict of interest. 


\section{References}

1. EFSA Panel on Dietetic Products, Nutrition and Allergies (NDA). Scientific Opinion on Dietary Reference Values for magnesium. Efsa J. 2015, 13, 4186. [CrossRef]

2. Jahnen-Dechent, W.; Ketteler, M. Magnesium basics. CKJ Clin. Kidney J. 2012, 5, 3-14. [CrossRef] [PubMed]

3. De Baaij, J.H.F.; Hoenderop, J.G.J.; Bindels, R.J.M. Magnesium in man: Implications for health and disease. Physiol. Rev. 2015, 95, 1-46. [CrossRef]

4. Saltiel, A.R.; Olefsky, J.M. Inflammatory mechanisms linking obesity and metabolic disease. J. Clin. Investig. 2017, 127, 1-4. [CrossRef] [PubMed]

5. Von Ehrlich, B.; Barbagallo, M.; Classen, H.G.; Guerrero-Romero, F.; Mooren, F.C.; Rodriguez-Moran, M.; Vierling, W.; Vormann, J.; Kisters, K. Significance of magnesium in insulin resistance, metabolic syndrome, and diabetes-Recommendations of the Association of Magnesium Research e.V. Trace Elem. Electrolytes 2017, 34, 124-129. [CrossRef]

6. Nielsen, F.H. Effects of magnesium depletion on inflammation in chronic disease. Curr. Opin. Clin. Nutr. Metab. Care 2014, 17, 525-530. [CrossRef]

7. Nielsen, F.H. Magnesium deficiency and increased inflammation: Current perspectives. J. Inflamm. Res. 2018, 11, 25-34. [CrossRef]

8. Mazidi, M.; Rezaie, P.; Banach, M. Effect of magnesium supplements on serum C-reactive protein: A systematic review and meta-analysis. Arch. Med. Sci. 2018, 14, 707-716. [CrossRef]

9. Lobionda, S.; Sittipo, P.; Kwon, H.Y.; Lee, Y.K. The role of gut microbiota in intestinal inflammation with respect to diet and extrinsic stressors. Microorganisms 2019, 7, 271. [CrossRef]

10. Oh, H.E.; Deeth, H.C. Magnesium in milk. Int. Dairy J. 2017, 71, 89-97. [CrossRef]

11. Gröber, U.; Schmidt, J.; Kisters, K. Magnesium in prevention and therapy. Nutrients 2015, 7, 8199-8226. [CrossRef] [PubMed]

12. Nielsen, F.H. The Problematic Use of Dietary Reference Intakes to Assess Magnesium Status and Clinical Importance. Biol. Trace Elem. Res. 2019, 188, 52-59. [CrossRef] [PubMed]

13. Costello, R.B.; Elin, R.J.; Rosanoff, A.; Wallace, T.C.; Guerrero-Romero, F.; Hruby, A.; Lutsey, P.L.; Nielsen, F.H.; Rodriguez-Moran, M.; Song, Y.; et al. Perspective: The Case for an Evidence-Based Reference Interval for Serum Magnesium: The Time Has Come. Adv. Nutr. Int. Rev. J. 2016, 7, 977-993. [CrossRef]

14. Lowenstein, F.W.; Stanton, M.F. Serum Magnesium Levels in The United States, 1971-1974. J. Am. Coll. Nutr. 1986, 5, 399-414. [CrossRef] [PubMed]

15. Nielsen, F.H. Guidance for the determination of status indicators and dietary requirements for magnesium. Magnes. Res. 2016, 29, 154-160. [CrossRef]

16. Razzaque, M.S. Magnesium: Are We Consuming Enough? Nutrients 2018, 10, 1863. [CrossRef]

17. Topf, J.M.; Murray, P.T. Hypomagnesemia and hypermagnesemia. Rev. Endocr. Metab. Disord. 2003, 4, 195-206. [CrossRef]

18. Al Alawi, A.M.; Majoni, S.W.; Falhammar, H. Magnesium and Human Health: Perspectives and Research Directions. Int. J. Endocrinol. 2018, 2018. [CrossRef]

19. Beaudart, C.; Locquet, M.; Touvier, M.; Reginster, J.Y.; Bruyère, O. Association between dietary nutrient intake and sarcopenia in the SarcoPhAge study. Aging Clin. Exp. Res. 2019, 31, 815-824. [CrossRef]

20. Van Dronkelaar, C.; Van Velzen, A.; Abdelrazek, M.; Van der Steen, A.; Weijs, P.J.M.; Tieland, M. Minerals and Sarcopenia; The Role of Calcium, Iron, Magnesium, Phosphorus, Potassium, Selenium, Sodium, and Zinc on Muscle Mass, Muscle Strength, and Physical Performance in Older Adults: A Systematic Review. J. Am. Med. Dir. Assoc. 2018, 19, 6-11.e3. [CrossRef]

21. Rude, R.K.; Gruber, H.E. Magnesium deficiency and osteoporosis: Animal and human observations. J. Nutr. Biochem. 2004, 15, 710-716. [CrossRef] [PubMed]

22. Ford, E.S.; Mokdad, A.H. Dietary magnesium intake in a national sample of US adults. J. Nutr. 2003, 133, $2879-2882$. [CrossRef] [PubMed]

23. Olza, J.; Aranceta-Bartrina, J.; González-Gross, M.; Ortega, R.M.; Serra-Majem, L.; Varela-Moreiras, G.; Gil, Á. Reported dietary intake, disparity between the reported consumption and the level needed for adequacy and food sources of calcium, phosphorus, magnesium and vitamin D in the Spanish population: Findings from the ANIBES study. Nutrients 2017, 9, 168. [CrossRef] [PubMed]

24. Tarleton, E.K. Factors influencing magnesium consumption among adults in the United States. Nutr. Rev. 2018, 76, 526-538. [CrossRef] [PubMed]

25. Rondanelli, M.; Faliva, M.A.; Gasparri, C.; Peroni, G.; Naso, M.; Picciotto, G.; Riva, A.; Nichetti, M.; Infantino, V.; Alalwan, T.A.; et al. Micronutrients dietary supplementation advices for celiac patients on long-term gluten-free diet with good compliance: A review. Medicine 2019, 55, 337. [CrossRef] [PubMed]

26. Galland, L. Magnesium and inflammatory bowel disease. Magnesium 1988, 7, 78-83.

27. Kruis, W.; Phuong Nguyen, G. Iron Deficiency, Zinc, Magnesium, Vitamin Deficiencies in Crohn's Disease: Substitute or Not? Dig. Dis. 2016, 34, 105-111. [CrossRef]

28. Owczarek, D.; Rodacki, T.; Domagała-Rodacka, R.; Cibor, D.; Mach, T. Diet and nutritional factors in inflammatory bowel diseases. World J. Gastroenterol. 2016, 22, 895-905. [CrossRef]

29. Dinicolantonio, J.J.; O'keefe, J.H.; Wilson, W. Subclinical magnesium deficiency: A principal driver of cardiovascular disease and a public health crisis Coronary artery disease. Open Hear. 2018, 5, 668. [CrossRef]

30. Bateman, S.W. A Quick Reference on Magnesium. Vet. Clin. N. Am. Small Anim. Pract. 2017, 47, 235-239. [CrossRef] 
31. Chrysant, S.G. Proton pump inhibitor-induced hypomagnesemia complicated with serious cardiac arrhythmias. Expert Rev. Cardiovasc. 2019, 17, 345-351. [CrossRef] [PubMed]

32. Grochowski, C.; Blicharska, E.; Baj, J.; Mierzwínska, A.; Brzozowska, K.; Forma, A.; MacIejewski, R. Serum iron, magnesium, copper, and manganese levels in alcoholism: A systematic review. Molecules 2019, 24, 1361. [CrossRef] [PubMed]

33. Maguire, D.; Ross, D.P.; Talwar, D.; Forrest, E.; Naz Abbasi, H.; Leach, J.P.; Woods, M.; Zhu, L.Y.; Dickson, S.; Kwok, T.; et al. Low serum magnesium and 1-year mortality in alcohol withdrawal syndrome. Eur. J. Clin. Investig. 2019, 49 , e13152. [CrossRef] [PubMed]

34. Viering, D.H.H.M.; De Baaij, J.H.F.; Walsh, S.B.; Kleta, R.; Bockenhauer, D. Genetic causes of hypomagnesemia, a clinical overview. Pediatr. Nephrol. 2017, 32, 1123-1135. [CrossRef]

35. López-González, B.; Molina-López, J.; Florea, D.I.; Quintero-Osso, B.; Pérez De La Cruz, A.; Ma, E.; Del Pozo, P. Association between magnesium-deficient status and anthropometric and clinical-nutritional parameters in posmenopausal women. Nutr Hosp. 2014, 29, 658-664. [CrossRef]

36. Touitou, Y.; Godard, J.P.; Ferment, O.; Chastang, C.; Proust, J.; Bogdan, A.; Auzéby, A.; Touitou, C. Prevalence of magnesium and potassium deficiencies in the elderly. Clin. Chem. 1987, 33, 518-523. [CrossRef]

37. Nielsen, F.H. Magnesium, inflammation, and obesity in chronic disease. Nutr. Rev. 2010, 68, 333-340. [CrossRef]

38. Maier, J.A.; Castiglioni, S.; Locatelli, L.; Zocchi, M.; Mazur, A. Magnesium and inflammation: Advances and perspectives. Semin. Cell Dev. Biol. 2020. [CrossRef]

39. Morais, J.B.S.; Severo, J.S.; Dos Santos, L.R.; De Sousa Melo, S.R.; De Oliveira Santos, R.; De Oliveira, A.R.S.; Cruz, K.J.C.; Do Nascimento Marreiro, D. Role of Magnesium in Oxidative Stress in Individuals with Obesity. Biol. Trace Elem. Res. 2017, 176, 20-26. [CrossRef]

40. Jiang, S.; Ma, X.; Li, M.; Yan, S.; Zhao, H.; Pan, Y.; Wang, C.; Yao, Y.; Jin, L.; Li, B. Association between dietary mineral nutrient intake, body mass index, and waist circumference in U.S. Adults using quantile regression analysis NHANES 2007-2014. PeerJ 2020, 8, e9127. [CrossRef]

41. Kelly, O.J.; Gilman, J.C.; Kim, Y.; Ilich, J.Z. Macronutrient Intake and Distribution in the Etiology, Prevention and Treatment of Osteosarcopenic Obesity. Curr. Aging Sci. 2016, 10, 83-105. [CrossRef]

42. Galan, P.; Preziosi, P.; Durlach, V.; Valeix, P.; Ribas, L.; Bouzid, D.; Favier, A.; Hercberg, S. Dietary magnesium intake in a French adult population. Magnes. Res. 1997, 10, 321-328. [CrossRef] [PubMed]

43. Lu, L.; Chen, C.; Yang, K.; Zhu, J.; Xun, P.; Shikany, J.M.; He, K. Magnesium intake is inversely associated with risk of obesity in a 30-year prospective follow-up study among American young adults. Eur. J. Nutr. 2020, 59, 3745-3753. [CrossRef] [PubMed]

44. Devaux, S.; Adrian, M.; Laurant, P.; Berthelot, A.; Quignard-Boulangé, A. Dietary magnesium intake alters age-related changes in rat adipose tissue cellularity. Magnes. Res. 2016, 29, 175-183. [CrossRef] [PubMed]

45. Castellanos-Gutiérrez, A.; Sánchez-Pimienta, T.G.; Carriquiry, A.; Da Costa, T.H.M.; Ariza, A.C. Higher dietary magnesium intake is associated with lower body mass index, waist circumference and serum glucose in Mexican adults. Nutr. J. 2018, 17, 114. [CrossRef]

46. He, K.; Liu, K.; Daviglus, M.L.; Morris, S.J.; Loria, C.M.; Van Horn, L.; Jacobs, D.R.; Savage, P.J. Magnesium intake and incidence of metabolic syndrome among young adults. Circulation 2006, 113, 1675-1682. [CrossRef]

47. Shamnani, G.; Rukadikar, C.; Gupta, V.; Singh, S.; Tiwari, S.; Bhartiy, S.; Sharma, P. Serum magnesium in relation with obesity. Natl. J. Physiol. Pharm. Pharm. 2018, 8, 1074-1077. [CrossRef]

48. Maguire, D.; Talwar, D.; Shiels, P.G.; McMillan, D. The role of thiamine dependent enzymes in obesity and obesity related chronic disease states: A systematic review. Clin. Nutr. ESPEN 2018, 25, 8-17. [CrossRef]

49. Mishra, S.; Padmanaban, P.; Deepti, G.N.; Sarkar, G.; Sumathi, S.; Toora, B.D. Serum magnesium and dyslipidemia in type-2 diabetes mellitus. Biomed. Res. 2012, 23, 295-300.

50. Ansari, M.R.; Maheshwari, N.; Shaikh, M.A.; Laghari, M.S.; Darshana; Lal, K.; Ahmed, K. Correlation of serum magnesium with dyslipidemia in patients on maintenance hemodialysis. Saudi J. Kidney Dis. Transpl. 2012, 23, 21-25. [CrossRef]

51. Deepti, R.; Nalini, G. Anbazhagan Relationship between hypomagnesemia and dyslipidemia in type 2 diabetes mellitus. Asian J. Pharm. Res. Health Care 2014, 6, 32-36.

52. Pereira-Santos, M.; Costa, P.R.F.; Assis, A.M.O.; Santos, C.A.S.T.; Santos, D.B. Obesity and vitamin D deficiency: A systematic review and meta-analysis. Obes. Rev. 2015, 16, 341-349. [CrossRef] [PubMed]

53. Rafiq, S.; Jeppesen, P.B. Body mass index, vitamin d, and type 2 diabetes: A systematic review and meta-analysis. Nutrients 2018, 10, 1182. [CrossRef] [PubMed]

54. Uwitonze, A.M.; Razzaque, M.S. Role of magnesium in vitamin d activation and function. J. Am. Osteopath. Assoc. 2018, 118, 181-189. [CrossRef] [PubMed]

55. Dai, Q.; Zhu, X.; Manson, J.A.E.; Song, Y.; Li, X.; Franke, A.A.; Costello, R.B.; Rosanoff, A.; Nian, H.; Fan, L.; et al. Magnesium status and supplementation influence Vitamin D status and metabolism: Results from a randomized trial. Am. J. Clin. Nutr. 2018, 108, 1249-1258. [CrossRef] [PubMed]

56. Al-Khalidi, B.; Kimball, S.M.; Rotondi, M.A.; Ardern, C.I. Standardized serum 25-hydroxyvitamin D concentrations are inversely associated with cardiometabolic disease in U.S. adults: A cross-sectional analysis of NHANES, 2001-2010. Nutr. J. 2017, 16, 16. [CrossRef] [PubMed] 
57. Stokic, E.; Romani, A.; Ilincic, B.; Kupusinac, A.; Stosic, Z.; Isenovic, E.R. Chronic Latent Magnesium Deficiency in Obesity Decreases Positive Effects of Vitamin D on Cardiometabolic Risk Indicators. Curr. Vasc. Pharm. 2018, 16, 610-617. [CrossRef]

58. Farhanghi, M.A.; Mahboob, S.; Ostadrahimi, A. Obesity induced Magnesium deficiency can be treated by vitamin D supplementation. J. Pak. Med. Assoc. 2009, 59, 258-261.

59. Song, Y.; Ridker, P.M.; Manson, J.A.E.; Cook, N.R.; Buring, J.E.; Liu, S. Magnesium intake, C-reactive protein, and the prevalence of metabolic syndrome in middle-aged and older U.S. women. Diabetes Care 2005, 28, 1438-1444. [CrossRef]

60. McKeown, N.M.; Jacques, P.F.; Zhang, X.L.; Juan, W.; Sahyoun, N.R. Dietary magnesium intake is related to metabolic syndrome in older Americans. Eur. J. Nutr. 2008, 47, 210-216. [CrossRef]

61. Mirmiran, P.; Shab-Bidar, S.; Hosseini-Esfahani, F.; Asghari, G.; Hosseinpour-Niazi, S.; Azizi, F. Magnesium intake and prevalence of metabolic syndrome in adults: Tehran lipid and glucose study. Public Health Nutr. 2012, 15, 693-701. [CrossRef] [PubMed]

62. Choi, M.K.; Bae, Y.J. Relationship between dietary magnesium, manganese, and copper and metabolic syndrome risk in Korean Adults: The Korea national health and nutrition examination survey (2007-2008). Biol. Trace Elem. Res. 2013, 156, 56-66. [CrossRef] [PubMed]

63. Dibaba, D.T.; Xun, P.; Fly, A.D.; Yokota, K.; He, K. Dietary magnesium intake and risk of metabolic syndrome: A meta-analysis. Diabet. Med. 2014, 31, 1301-1309. [CrossRef]

64. Sarrafzadegan, N.; Khosravi-Boroujeni, H.; Lotfizadeh, M.; Pourmogaddas, A.; Salehi-Abargouei, A. Magnesium status and the metabolic syndrome: A systematic review and meta-analysis. Nutrition 2016, 32, 409-417. [CrossRef] [PubMed]

65. Yang, N.; He, L.; Li, Y.; Xu, L.; Ping, F.; Li, W.; Zhang, H. Reduced Insulin Resistance Partly Mediated the Association of High Dietary Magnesium Intake with Less Metabolic Syndrome in a Large Chinese Population. Diabetes. Metab. Syndr. Obes. 2020, 13, 2541-2550. [CrossRef]

66. Rasic-Milutinovic, Z.; Perunicic-Pekovic, G.; Jovanovic, D.; Gluvic, Z.; Cankovic-Kadijevic, M. Association of blood pressure and metabolic syndrome components with magnesium levels in drinking water in some Serbian municipalities. J. Water Health 2012, 10, 161-169. [CrossRef]

67. Fang, X.; Wang, K.; Han, D.; He, X.; Wei, J.; Zhao, L.; Imam, M.U.; Ping, Z.; Li, Y.; Xu, Y.; et al. Dietary magnesium intake and the risk of cardiovascular disease, type 2 diabetes, and all-cause mortality: A dose-response meta-analysis of prospective cohort studies. BMC Med. 2016, 14, 210. [CrossRef]

68. Zhang, W.; Iso, H.; Ohira, T.; Date, C.; Tamakoshi, A. Associations of dietary magnesium intake with mortality from cardiovascular disease: The JACC study. Atherosclerosis 2012, 221, 587-595. [CrossRef]

69. Veronese, N.; Watutantrige-Fernando, S.; Luchini, C.; Solmi, M.; Sartore, G.; Sergi, G.; Manzato, E.; Barbagallo, M.; Maggi, S.; Stubbs, B. Effect of magnesium supplementation on glucose metabolism in people with or at risk of diabetes: A systematic review and meta-analysis of double-blind randomized controlled trials. Eur. J. Clin. Nutr. 2016, 70, 1354-1359. [CrossRef]

70. Veronese, N.; Demurtas, J.; Pesolillo, G.; Celotto, S.; Barnini, T.; Calusi, G.; Caruso, M.G.; Notarnicola, M.; Reddavide, R.; Stubbs, B.; et al. Magnesium and health outcomes: An umbrella review of systematic reviews and meta-analyses of observational and intervention studies. Eur. J. Nutr. 2020, 59, 263-272. [CrossRef]

71. Rosique-Esteban, N.; Guasch-Ferré, M.; Hernández-Alonso, P.; Salas-Salvadó, J. Dietary magnesium and cardiovascular disease: A review with emphasis in epidemiological studies. Nutrients 2018, 10, 168. [CrossRef] [PubMed]

72. Maria De Lourdes, L.; Cruz, T.; Rodrigues, L.E.; Bomfim, O.; Melo, J.; Correia, R.; Porto, M.; Cedro, A.; Vicente, E. Serum and intracellular magnesium deficiency in patients with metabolic syndrome-Evidences for its relation to insulin resistance. Diabetes Res. Clin. Pract. 2009, 83, 257-262. [CrossRef]

73. Ghasemi, A.; Zahediasl, S.; Syedmoradi, L.; Azizi, F. Low serum magnesium levels in elderly subjects with metabolic syndrome. Biol. Trace Elem. Res. 2010, 136, 18-25. [CrossRef] [PubMed]

74. Wang, Y.; Wei, J.; Zeng, C.; Yang, T.; Li, H.; Cui, Y.; Xie, D.; Xu, B.; Liu, Z.; Li, J.; et al. Association between serum magnesium concentration and metabolic syndrome, diabetes, hypertension and hyperuricaemia in knee osteoarthritis: A cross-sectional study in Hunan Province, China. BMJ Open 2018, 8, e019159. [CrossRef] [PubMed]

75. Han, D.; Fang, X.; Su, D.; Huang, L.; He, M.; Zhao, D.; Zou, Y.; Zhang, R. Dietary Calcium Intake and the Risk of Metabolic Syndrome: A Systematic Review and Meta-Analysis. Sci. Rep. 2019, 9, 19046. [CrossRef] [PubMed]

76. Moore-Schiltz, L.; Albert, J.M.; Singer, M.E.; Swain, J.; Nock, N.L. Dietary intake of calcium and magnesium and the metabolic syndrome in the National Health and Nutrition Examination (NHANES) 2001-2010 data. Br. J. Nutr. 2015, 114, 924-935. [CrossRef]

77. Park, S.H.; Kim, S.K.; Bae, Y.J. Relationship between serum calcium and magnesium concentrations and metabolic syndrome diagnostic components in middle-aged Korean men. Biol. Trace Elem. Res. 2012, 146, 35-41. [CrossRef]

78. Dai, Q.; Shu, X.O.; Deng, X.; Xiang, Y.B.; Li, H.; Yang, G.; Shrubsole, M.J.; Ji, B.; Cai, H.; Chow, W.H.; et al. Modifying effect of calcium/magnesium intake ratio and mortality: A population based cohort study. BMJ Open 2013, 3, e002111. [CrossRef]

79. Dong, J.-Y.; Xun, P.; He, K.; Qin, L.-Q. Magnesium Intake and Risk of Type 2 Diabetes. Diabetes Care 2011, 34, 2116-2122. [CrossRef]

80. Bertinato, J.; Wang, K.C.; Hayward, S. Serum magnesium concentrations in the Canadian population and associations with diabetes, glycemic regulation, and insulin resistance. Nutrients 2017, 9, 296. [CrossRef]

81. Zhao, B.; Zeng, L.; Zhao, J.; Wu, Q.; Dong, Y.; Zou, F.; Gan, L.; Wei, Y.; Zhang, W. Association of magnesium intake with type 2 diabetes and total stroke: An updated systematic review and meta-analysis. BMJ Open 2020, 10, 32240. [CrossRef] [PubMed]

82. Barbagallo, M.; Dominguez, L.J. Magnesium metabolism in type 2 diabetes mellitus, metabolic syndrome and insulin resistance. Arch. Biochem. Biophys. 2007, 458, 40-47. [CrossRef] [PubMed] 
83. Esmeralda, C.A.C.; Ibrahim, S.N.A.; David, P.E.; Maldonado, I.C.; David, A.S.; Escorza, M.A.Q.; Dealmy, D.G. Deranged fractional excretion of magnesium and serum magnesium levels in relation to retrograde glycaemic regulation in patients with type 2 diabetes mellitus. Curr. Diabetes Rev. 2020, 17, 91-100. [CrossRef] [PubMed]

84. Fang, X.; Han, H.; Li, M.; Liang, C.; Fan, Z.; Aaseth, J.; He, J.; Montgomery, S.; Cao, Y. Dose-Response Relationship between Dietary Magnesium Intake and Risk of Type 2 Diabetes Mellitus: A Systematic Review and Meta-Regression Analysis of Prospective Cohort Studies. Nutrients 2016, 8, 739. [CrossRef] [PubMed]

85. Chacko, S.A.; Sul, J.; Song, Y.; Li, X.; LeBlanc, J.; You, Y.; Butch, A.; Liu, S. Magnesium supplementation, metabolic and inflammatory markers, and global genomic and proteomic profiling: A randomized, double-blind, controlled, crossover trial in overweight individuals. Am. J. Clin. Nutr. 2011, 93, 463-473. [CrossRef]

86. Mooren, F.C.; Krüger, K.; Völker, K.; Golf, S.W.; Wadepuhl, M.; Kraus, A. Oral magnesium supplementation reduces insulin resistance in non-diabetic subjects-A double-blind, placebo-controlled, randomized trial. Diabetes Obes. Metab. 2011, 13, 281-284. [CrossRef]

87. Hruby, A.; Guasch-Ferré, M.; Bhupathiraju, S.N.; Manson, J.E.; Willett, W.C.; McKeown, N.M.; Hu, F.B. Magnesium Intake, Quality of Carbohydrates, and Risk of Type 2 Diabetes: Results From Three U.S. Cohorts. Diabetes Care 2017, 40, 1695-1702. [CrossRef]

88. Ashcroft, F.M.; Puljung, M.C.; Vedovato, N. Neonatal Diabetes and the KATP Channel: From Mutation to Therapy. Trends Endocrinol. Metab. 2017, 28, 377-387. [CrossRef]

89. Kostov, K. Effects of magnesium deficiency on mechanisms of insulin resistance in type 2 diabetes: Focusing on the processes of insulin secretion and signaling. Int. J. Mol. Sci. 2019, 20, 1351. [CrossRef]

90. Günther, $\mathrm{T}$. The biochemical function of $\mathrm{Mg} 2+$ in insulin secretion, insulin signal transduction and insulin resistance. Magnes. Res. 2010, 23, 5-18. [CrossRef]

91. Gommers, L.M.M.; Hoenderop, J.G.J.; Bindels, R.J.M.; De Baaij, J.H.F. Hypomagnesemia in Type 2 Diabetes: A Vicious Circle? Diabetes 2016, 65, 3-13. [CrossRef] [PubMed]

92. Apell, H.J.; Hitzler, T.; Schreiber, G. Modulation of the Na,K-ATPase by Magnesium Ions. Biochemistry 2017, 56, 1005-1016. [CrossRef] [PubMed]

93. Grycova, L.; Sklenovsky, P.; Lansky, Z.; Janovska, M.; Otyepka, M.; Amler, E.; Teisinger, J.; Kubala, M. ATP and magnesium drive conformational changes of the Na+/K+-ATPase cytoplasmic headpiece. Biochim. Biophys. Acta Biomembr. 2009, 1788, $1081-1091$. [CrossRef] [PubMed]

94. Nair, A.V.; Hocherb, B.; Verkaart, S.; Van Zeeland, F.; Pfab, T.; Slowinski, T.; Chen, Y.P.; Schlingmann, K.P.; Schaller, A.; Gallati, S.; et al. Loss of insulin-induced activation of TRPM6 magnesium channels results in impaired glucose tolerance during pregnancy. Proc. Natl. Acad. Sci. USA 2012, 109, 11324-11329. [CrossRef]

95. Hassan, S.A.U.; Ahmed, I.; Nasrullah, A.; Haq, S.; Ghazanfar, H.; Sheikh, A.B.; Zafar, R.; Askar, G.; Hamid, Z.; Khushdil, A.; et al. Comparison of Serum Magnesium Levels in Overweight and Obese Children and Normal Weight Children. Cureus 2017, 9, e1607. [CrossRef]

96. Zaakouk, A.M.; Hassan, M.A.; Tolba, O.A. Serum magnesium status among obese children and adolescents. Egypt. Pediatr. Assoc. Gaz. 2016, 64, 32-37. [CrossRef]

97. Huerta, M.G.; Roemmich, J.N.; Kington, M.L.; Bovbjerg, V.E.; Weltman, A.L.; Holmes, V.F.; Patrie, J.T.; Rogol, A.D.; Nadler, J.L. Magnesium deficiency is associated with insulin resistance in obese children. Diabetes Care 2005, 28, 1175-1181. [CrossRef]

98. Le Chatelier, E.; Nielsen, T.; Qin, J.; Prifti, E.; Hildebrand, F.; Falony, G.; Almeida, M.; Arumugam, M.; Batto, J.-M.; Kennedy, S.; et al. Richness of human gut microbiome correlates with metabolic markers. Nature 2013, 500, 541-546. [CrossRef]

99. Wang, M.; Monaco, M.H.; Donovan, S.M. Impact of early gut microbiota on immune and metabolic development and function. Semin. Fetal Neonatal Med. 2016, 21, 380-387. [CrossRef]

100. Parekh, P.J.; Balart, L.A.; Johnson, D.A. The influence of the gut microbiome on obesity, metabolic syndrome and gastrointestinal disease. Clin. Transl. Gastroenterol. 2015, 6, e91. [CrossRef]

101. Pyndt Jørgensen, B.; Winther, G.; Kihl, P.; Nielsen, D.S.; Wegener, G.; Hansen, A.K.; Sørensen, D.B. Dietary magnesium deficiency affects gut microbiota and anxiety-like behaviour in C57BL/6N mice. Acta Neuropsychiatr. 2015, 27, 307-311. [CrossRef] [PubMed]

102. Winther, G.; Pyndt Jørgensen, B.M.; Elfving, B.; Nielsen, D.S.; Kihl, P.; Lund, S.; Sørensen, D.B.; Wegener, G. Dietary magnesium deficiency alters gut microbiota and leads to depressive-like behaviour. Acta Neuropsychiatr. 2015, 27, 168-176. [CrossRef] [PubMed]

103. Luppino, F.S.; De Wit, L.M.; Bouvy, P.F.; Stijnen, T.; Cuijpers, P.; Penninx, B.W.J.H.; Zitman, F.G. Overweight, obesity, and depression: A systematic review and meta-analysis of longitudinal studies. Arch. Gen. Psychiatry 2010, 67, 220-229. [CrossRef] [PubMed]

104. Chang, P.; Friedenberg, F. Obesity and GERD. Gastroenterol. Clin. N. Am. 2014, 43, 161-173. [CrossRef]

105. Gommers, L.M.M.; Ederveen, T.H.A.; Van Der Wijst, J.; Overmars-Bos, C.; Kortman, G.A.M.; Boekhorst, J.; Bindels, R.J.M.; De Baaij, J.H.F.; Hoenderop, J.G.J. Low gut microbiota diversity and dietary magnesium intake are associated with the development of PPI-induced hypomagnesemia. FASEB J. 2019, 33, 11235-11246. [CrossRef]

106. Pachikian, B.D.; Neyrinck, A.M.; Deldicque, L.; De Backer, F.C.; Catry, E.; Dewulf, E.M.; Sohet, F.M.; Bindels, L.B.; Everard, A.; Francaux, M.; et al. Changes in intestinal bifidobacteria levels are associated with the inflammatory response in magnesiumdeficient mice. J. Nutr. 2010, 140, 509-514. [CrossRef]

107. Cox, A.J.; West, N.P.; Cripps, A.W. Obesity, inflammation, and the gut microbiota. Lancet Diabetes Endocrinol. 2015, 3, 207-215. [CrossRef] 
108. Saad, M.J.A.; Santos, A.; Prada, P.O. Linking gut microbiota and inflammation to obesity and insulin resistance. Physiology 2016, 31, 283-293. [CrossRef] [PubMed]

109. Schoeler, M.; Caesar, R. Dietary lipids, gut microbiota and lipid metabolism. Rev. Endocr. Metab. Disord. 2019, 20, 461-472. [CrossRef]

110. Semenkovich, C.F.; Danska, J.; Darsow, T.; Dunne, J.L.; Huttenhower, C.; Insel, R.A.; McElvaine, A.T.; Ratner, R.E.; Shuldiner, A.R.; Blaser, M.J. American Diabetes Association and JDRF Research Symposium: Diabetes and the Microbiome. Diabetes 2015, 64, 3967-3977. [CrossRef]

111. Caesar, R. Pharmacologic and Nonpharmacologic Therapies for the Gut Microbiota in Type 2 Diabetes. Can. J. Diabetes 2019, 43, 224-231. [CrossRef]

112. Nuli, R.; Cai, J.; Kadeer, A.; Zhang, Y.; Mohemaiti, P. Integrative Analysis Toward Different Glucose Tolerance-Related Gut Microbiota and Diet. Front. Endocrinol. (Lausanne) 2019, 10, 295. [CrossRef] [PubMed]

113. Thingholm, L.B.; Rühlemann, M.C.; Koch, M.; Fuqua, B.; Laucke, G.; Boehm, R.; Bang, C.; Franzosa, E.A.; Hübenthal, M.; Rahnavard, A.; et al. Obese Individuals with and without Type 2 Diabetes Show Different Gut Microbial Functional Capacity and Composition. Cell Host Microbe 2019, 26, 252-264.e10. [CrossRef]

114. Crowley, E.K.; Long-Smith, C.M.; Murphy, A.; Patterson, E.; Murphy, K.; O'Gorman, D.M.; Stanton, C.; Nolan, Y.M. Dietary supplementation with a magnesium-rich marine mineral blend enhances the diversity of gastrointestinal microbiota. Mar. Drugs 2018, 16, 216. [CrossRef] [PubMed]

115. Cazzola, R.; Della Porta, M.; Manoni, M.; Iotti, S.; Pinotti, L.; Maier, J.A. Going to the roots of reduced magnesium dietary intake: A tradeoff between climate changes and sources. Helyon 2020, 6, e05390. [CrossRef] [PubMed]

116. Elderawi, W.A.; Naser, I.A.; Taleb, M.H.; Abutair, A.S. The Effects of Oral Magnesium Supplementation on Glycemic Response among Type 2 Diabetes Patients. Nutrients 2018, 11, 44. [CrossRef] [PubMed]

117. Navarrete-Cortes, A.; Ble-Castillo, J.L.; Guerrero-Romero, F.; Cordova-Uscanga, R.; Juárez-Rojop, I.E.; Aguilar-Mariscal, H.; Tovilla-Zarate, C.A.; Del Rocio Lopez-Guevara, M. No effect of magnesium supplementation on metabolic control and insulin sensitivity in type 2 diabetic patients with normomagnesemia. Magnes. Res. 2014, 27, 48-56. [CrossRef]

118. Razzaghi, R.; Pidar, F.; Momen-Heravi, M.; Bahmani, F.; Akbari, H.; Asemi, Z. Magnesium Supplementation and the Effects on Wound Healing and Metabolic Status in Patients with Diabetic Foot Ulcer: A Randomized, Double-Blind, Placebo-Controlled Trial. Biol. Trace Elem. Res. 2018, 181, 207-215. [CrossRef]

119. Simental-Mendía, L.E.; Rodríguez-Morán, M.; Reyes-Romero, M.A.; Guerrero-Romero, F. No positive effect of oral magnesium supplementation in the decreases of inflammation in subjects with prediabetes: A pilot study. Magnes. Res. 2012, 25, 140-146. [CrossRef]

120. Steward, C.J.; Zhou, Y.; Keane, G.; Cook, M.D.; Liu, Y.; Cullen, T. One week of magnesium supplementation lowers IL-6, muscle soreness and increases post-exercise blood glucose in response to downhill running. Eur. J. Appl. Physiol. 2019, 119, 2617-2627. [CrossRef]

121. Dibaba, D.T.; Xun, P.; Song, Y.; Rosanoff, A.; Shechter, M.; He, K. The effect of magnesium supplementation on blood pressure in individuals with insulin resistance, prediabetes, or noncommunicable chronic diseases: A meta-analysis of randomized controlled trials. Am. J. Clin. Nutr. 2017, 106, 921-929. [CrossRef] [PubMed]

122. Banjanin, N.; Belojevic, G. Changes of blood pressure and hemodynamic parameters after oral magnesium supplementation in patients with essential hypertension—an intervention study. Nutrients 2018, 10, 581. [CrossRef] [PubMed]

123. Hatzistavri, L.S.; Sarafidis, P.A.; Georgianos, P.I.; Tziolas, I.M.; Aroditis, C.P.; Zebekakis, P.E.; Pikilidou, M.I.; Lasaridis, A.N. Oral magnesium supplementation reduces ambulatory blood pressure in patients with mild hypertension. Am. J. Hypertens. 2009, 22, 1070-1075. [CrossRef] [PubMed]

124. Rodríguez-Ramírez, M.; Rodríguez-Morán, M.; Reyes-Romero, M.A.; Guerrero-Romero, F. Effect of oral magnesium supplementation on the transcription of TRPM6, TRPM7, and SLC41A1 in individuals newly diagnosed of pre-hypertension. A randomized, double-blind, placebo-controlled trial. Magnes. Res. 2017, 30, 80-87. [CrossRef] [PubMed]

125. Cunha, A.R.; D’El-Rei, J.; Medeiros, F.; Umbelino, B.; Oigman, W.; Touyz, R.M.; Neves, M.F. Oral magnesium supplementation improves endothelial function and attenuates subclinical atherosclerosis in thiazide-treated hypertensive women. J. Hypertens. 2017, 35, 89-97. [CrossRef] [PubMed]

126. Mortazavi, M.; Moeinzadeh, F.; Saadatnia, M.; Shahidi, S.; McGee, J.C.; Minagar, A. Effect of magnesium supplementation on carotid intima-media thickness and flow-mediated dilatation among hemodialysis patients: A double-blind, randomized, placebo-controlled trial. Eur. Neurol. 2013, 69, 309-316. [CrossRef] [PubMed]

127. Joris, P.J.; Plat, J.; Bakker, S.J.L.; Mensink, R.P. Effects of long-term magnesium supplementation on endothelial function and cardiometabolic risk markers: A randomized controlled trial in overweight/obese adults. Sci. Rep. 2017, 7, 106. [CrossRef]

128. Rodríguez-Morán, M.; Simental-Mendía, L.E.; Gamboa-Gómez, C.I.; Guerrero-Romero, F. Oral Magnesium Supplementation and Metabolic Syndrome: A Randomized Double-Blind Placebo-Controlled Clinical Trial. Adv. Chronic Kidney Dis. 2018, 25, 261-266. [CrossRef]

129. Simental-Mendía, L.E.; Simental-Mendía, M.; Sahebkar, A.; Rodríguez-Morán, M.; Guerrero-Romero, F. Effect of magnesium supplementation on lipid profile: A systematic review and meta-analysis of randomized controlled trials. Eur. J. Clin. Pharmacol. 2017, 73, 525-536. [CrossRef] 
130. Cosaro, E.; Bonafini, S.; Montagnana, M.; Danese, E.; Trettene, M.S.; Minuz, P.; Delva, P.; Fava, C. Effects of magnesium supplements on blood pressure, endothelial function and metabolic parameters in healthy young men with a family history of metabolic syndrome. Nutr. Metab. Cardiovasc. Dis. 2014, 24, 1213-1220. [CrossRef]

131. Firoz, M.; Graber, M. Bioavallability of US commercial magnesium preparations. Magnes. Res. 2001, 14, 257-262. [PubMed]

132. Verhas, M.; De, V.; Guéronnière, L.; Grognet, J.-M.; Paternot, J.; Hermanne, A.; Van Den Winkel, P.; Gheldof, R.; Martin, P.; Fantino, M.; et al. Magnesium bioavailability from mineral water. A study in adult men. Eur. J. Clin. Nutr. 2002, 56, $442-447$. [CrossRef] [PubMed]

133. Coudray, C.; Rambeau, M.; Feillet-Coudray, C.; Gueux, E.; Tressol, J.C.; Mazur, A.; Rayssiguier, Y. Study of magnesium bioavailability from ten organic and inorganic $\mathrm{Mg}$ salts in $\mathrm{Mg}$-depleted rats using a stable isotope approach. Magnes. Res. 2005, 18, 215-223. [PubMed]

134. Uysal, N.; Kizildag, S.; Yuce, Z.; Guvendi, G.; Kandis, S.; Koc, B.; Karakilic, A.; Camsari, U.M.; Ates, M. Timeline (Bioavailability) of Magnesium Compounds in Hours: Which Magnesium Compound Works Best? Biol. Trace Elem. Res. 2019, 187, 128-136. [CrossRef] [PubMed]

135. Lindberg, J.S.; Zobitz, M.M.; Poindexter, J.R.; Pak, C.Y.C. Magnesium bioavailability from magnesium citrate and magnesium oxide. J. Am. Coll. Nutr. 1990, 9, 48-55. [CrossRef]

136. Ates, M.; Kizildag, S.; Yuksel, O.; Hosgorler, F.; Yuce, Z.; Guvendi, G.; Kandis, S.; Karakilic, A.; Koc, B.; Uysal, N. Dose-Dependent Absorption Profile of Different Magnesium Compounds. Biol. Trace Elem. Res. 2019, 192, 244-251. [CrossRef] 